症例

慢性膵炎に対する十二指腸温存膵頭切除術を施行した 2 例

札幌医科大学第 1 外科（主任：平田公一教授）

$\begin{array}{llllllll}\text { 木 村 } & \text { 雅 } & \text { 美平田公 一 } & \text { 三 神 俊 彦 } \\ \text { 及 川 } & \text { 郁 雄 向 谷充宏 伝 野 隆一 }\end{array}$

慢性膵炎に起因する腹痛は，しばしば内科的治療に抵抗を示し，外科治療を要するこ とがある. 教室では1990年まで膆頭部に病変の限局した慢性脺炎症例（主として主膵管 拡張非著明例) に対し，膵頭十二指腸切除術を適応としてきた。一方，1980年に Beger らが十二指腸温存膵頭切除術 (以下 DpPHR) を報告して以来, Beger の手技に工夫を加 えた DpPHR が報告されてきた。教室でも膵頭部に限局した慢性脺炎にDpPHR を施行 し, 良好な成績を得た代表的な 2 例を報告する. 術式としては, Kocher 授動術を施行せ ず, また後上膵十二指腸動脈, 胆管を温存し, 再建法として Roux-Y 型膵空腸吻合法を 行った. 2 例目の経験より, 合目的的な血管温存が可能であれぼ, Kocher 授動術も許容 されるのではないかと示唆された. DpPHR は手技上の論議がなおあるが, 消化管の持つ 本来の機能をより温存し得る術式として解剖, 生理学的に明らかになることが期待され る.

卖引用語：慢性脺炎, 十二指腸温存膵頭切除術

\section{緒 言}

慢性膵炎に対する外科的治療としては脺切除術と脺 管減圧術に大別される. 教室では膵温存術式としての 減圧術を基本としてきた。一方て膵頭部に病変の主座 があり, かつ尾側主膵管に拡張を伴わない慢性勝炎症 例に対しては根治性を優先し脺頭十二指腸切除術を適 応としてきた，後者については，病巣の大きさ・性状 に比し大量の組織切除となるため, 術後に著しい消 化・吸収障害を生じるという欠点があった。

1980年に Beger らが，可及的に十二指腸を温存し膵 頭部を切除する十二指腸温存膵頭切除術 (duodenumpreserving pancreas head resection (以下 DpPHR)) を報告して以来”，内外の各施設で追試がなされてき た．報告者間で術式に若干の差があるものの，本術式 が消化・吸収能を含めた術後の生理的機能の維持に意 義のある術式であることは諸家の認めるところであ る.

今回, 教室で Kocher の授動術をせずに操作を進め, 胆道を温存しえたDpPHR 2 症例を経験したので,こ れを報告するとともに，な拉議のある術式，再建法

1995年 1 月23日受付 1996年 3 月27日採用
について私見を述へ，文献的に検討した。

$$
\text { 症例 }
$$

症例 $1: 65$ 歳, 男性.

主訴：上腹部痛.

既往歴および家族歴：特記すべき事なし.

飲酒歴：日本酒 4 合/日 $\times 45$ 年.

現病歴: 平成 3 年 7 月, 腹部から背部への放散痛, 嘔気が出現し，近医入院となる，胆喜内およひ膵管内 結石の存在を指摘された. その後, 著変なく経過した が，再度同様の症状が出現したため精査目的で当科入 院となる.

入院時現症：特記すべき事なし。

入院時検査所見：血算,生化学検査值に異常ないが, エラスターゼ-1は546ng/dl と高値を示した. $75 \mathrm{~g}$ OGTT で糖尿病型, PFD は71.7\%と若干低值を示し た。

腹部 CT 所見：Bolus CT では膵頭・鈎部，特に鈎部 に石灰化を示す不整形の high density spot と, 同部で の主膵管の拡張を認めた。

ERCP 所見：膵頭部に限局した主膵管の拡張, 粠管 内部の大小の陰影欠損および下頭枝の開大を認めた。

手術術式：以上の諸検査より膵頭部に主座を置く慢 

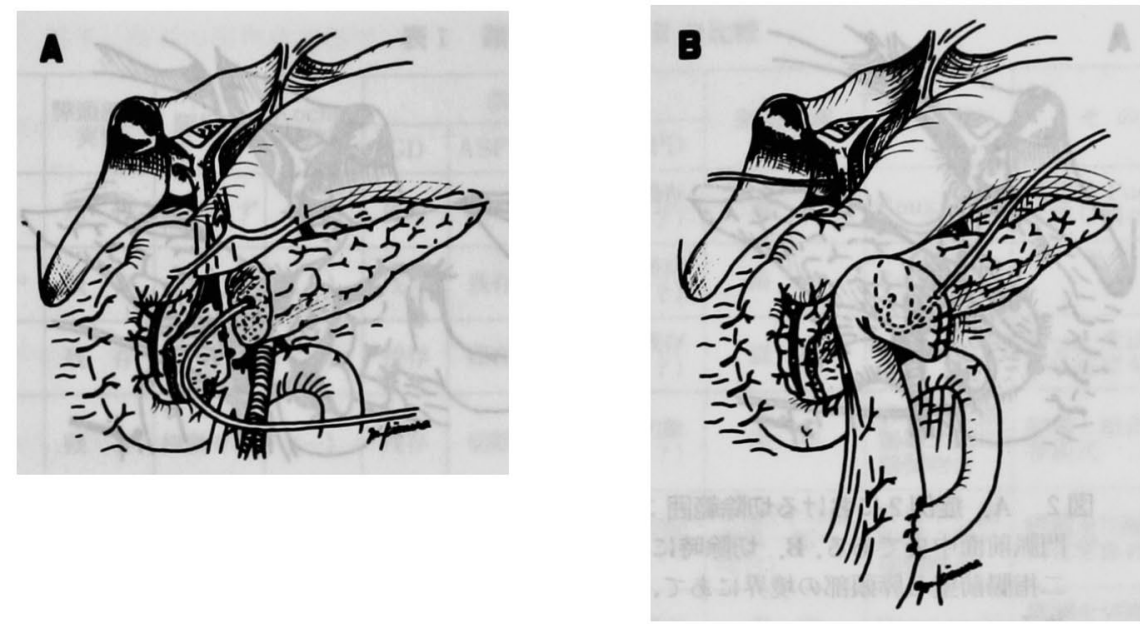

図 1 A. 症例 1 における切除笻囲：切離緣の右側は下部胆管左緑に沿い, 左側は主 脺管主病変の上流端の左側である.B. 再建術式：後結腸性に空腸を持ち上げ尾側 残膵と Roux-en-Y 型に端側吻合する.

性膵炎と診断し, DpPHR の適応と判断した。切除範囲 については十二指腸例の切離縁を下部胆管壁に浻う面 とし, 左側の切離線を主勝管病変の上流側端の左側と した (図 1A).

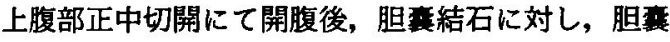
摘出術を施行した．次に脺頭部の周囲組織からの遊離 操作となるが,この際にはドレナージ静脈路温存のた め Kocher 授動術を施行しない，脺下縁で上腸間腸静 脈を露出後，門脈前面に沿って鈍的に勝後面のトンネ リングを行う．膵頭部は全体に硬く腫脹しており，そ の主たる病変部を充分に含むように，術前診断を念頭 におきつつ脺切離線を決定し，切離する．膵腹側の牂 膜を剝離しつつ, 肝動脈を露出し, 胃十二指腸動脈, 後上膵十二指腸動脈を温存し, 次に胆管壁左緑に沿っ て脺を切離する．膵鈎部は，膁から門脈への交通枝を 処理した後に上腸間膜動脈より下膵十二指腸動脈を切

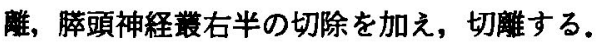

再建は，残存十二指腸壁の色調がやや不良であった ため，同部位に勝管を吻合することを避け，後結腸性 に空腸を持ち上げ尾側の残存脺に Roux-en-Y 型脺空 腸端側吻合を行った（図 1B)。

病理所見：脺は全体に線維化と外分泌腺の荒廃が著 しく，線維化組織中にラ氏島のみが連残する所見を認 めた。線維化の程度は諸星らの分類の Grade III に相 当した2).リンパ球浸潤を随所に認め, 慢性膵炎と診断 した.

症例 $2 ： 70$ 歳, 男性.
主訴：上腹部痛.

既往歴および家族歴：特記すべき事なし.

現病歴：上腹部痛に対し，近医で投薬治療を受ける も，改善傾向はなかった，各種画像診断により，胆褰 腫大・胆石症・脺蓄胞を指摘され当科入院となった。

入院時現症：特記すべき事なし。

入院時検査所見：一般血液検査, 生化学検㚗值に異 常を認めなかった．腫瘍マーカーについては CA19-9 が269U/ml, エラスターゼ-1が670ng/dl と高值を示し た. 75gOGTT は糖尿病型を示した。

ERCP 所見：膵頭部の主膵管・Santorini 管合流部 尾側に狭管像を認め，その尾側の主粠管は拡張してい た. 膆管内視鏡て，狭窄部と一致する脺管粘膜の発赤, 表面不整像を認めた。膵液細胞診では Class II ないし III に該当するものであった。

手術術式：以上の諸検査の結果から膵頭部の限局性 勝管内病変を疑い, DpPHR 適応と判断した. 膵切離緑 の, 右側は十二指腸壁との境界部, 左側は門脈前面中 央となった (図 2A). Kocher 授動術は症例 1 と同様に 行わなかった。

血管処理については膵前面において，右胃大網動脈 を前上膆十二指腸動脈との分枝部直後で結紮切離, 前 上脺十二指腸動脈も同時に結愁切離する，膵頭部を右 側に率引しつつ, 門脈右壁に流入する門脈枝を $3 \sim 4$ 本結愁し, 膵頭部後面の制離を行う。

次に膵頭神経叢右半部を切除した，膵後面で下部胆 管の脺流入部を確認し,これを慎重に剥離し温存する。 

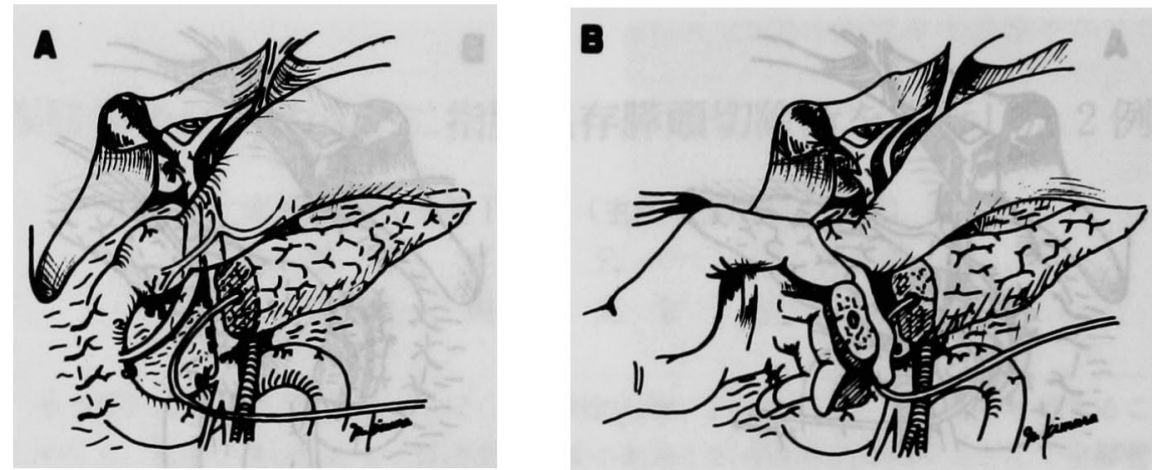

图 2 A. 症例 2 における切除筙囲：切離縁の右側は十二指腸壁との境界部, 左側は 門脈前面中央である. B. 切除時における工夫：膵後面剝離の際, 術者の左示指を十 二指腸前壁と膵頭部の境界にあて，左母指で脺頭部をめくるように丁掌に操作を進 める。

脺鈎部後方からの剥離を進めつつ, 可能な限り下脺十 二指腸動脈を温存した．膵頭部を挙上しつつ十二指腸 壁より剥離し，主膵管と副膵管を確認する。膵内胆管 を乳頭部に向かって剥離, 主脺管との合流部を確認後, 同部で主膵管を結禁切離する。

再建は症例 1 と同様に Roux-en-Y 型に行った。

病理所見：組織学的に脺管内の腫瘍性病変は認め ず，主膵管周囲の腺葉に軽度の線維化，間質の浮腫お よび軽度の炎症細胞浸漫を認めた．線維化の程度は Grade I で膵頭部主膵管に限局した慢性膵炎と診断し た.

術後 1 週目の Tチューブ造影で総胆管の乳頭側に 狭䇤像を認めた. 8 週後でも同様の狭窄像を認めるが, 直径 $6 \mathrm{~mm}$ の拡張バルーンが容易に挿入されることよ ク，機能的にはそれ以上の内径があると考えた．乳頭 部の Oddi 筋の機能が，保持されていることを胆道造 影にて確認した. 現在も胆管炎, 黄病などの発生はな い.

\section{考 察}

慢性脺炎に対する外科治療の主たる適応は内科的治 療に抵抗する頑固な疼痛である．除痛目的のために選 択される脺直接手術は，膵管ドレナージ手術と膡切除 術に大別できる，慢性膆炎における疼痛の主因が膀管 内圧の上昇であるという根拠に前者を推奖する研究者 は多( ${ }^{3 / 4)}$. 反面，今泉らは炎症を呈している膵実質を 切除しない限り，完全な除痛効果が得られないと報告 してきた5).しかし，両群における手術後の膵内外分泌 機能を比較すると膵切除術では, 術後の内外分泌機能 の低下が生じるという報告が多い6)。
疼痛の充分な寛解が得られ, かつ粠内外分泌能の保 持の優れた術式として，Beger らが十二指腸温存脺頭 切除術を報告したのは1980年のことである”。本術式 が病巣部の切除ばかりでなく, 術後脺機能温存をはか る優れたものであることは事実であり，以来，国内外 でいくつかの報告がなされている．

表 1 は DpPHR 報告例の手術手技を比較したもの であるが，各報告者により十二指腸の血流の確保，胆 道処理, 再建法等が異なっている(17) 11). Beger らは Kocher 授動術を脺頭切離に際して行っておりこの ため十二指腸の血流は胃十二指腸動脈と膵・十二指腸 動脈のアーケードに依存している．国内では加藤らが 1985年にすでに Beger 変法として報告しており，血流 温存も Beger らの報告に類似している778)。これに対 し, 安田, 今泉らの報告は十二指腸の血流を後上十二 指腸動脈と mesoduodenal vessels に依存する術式て あり，後者の温存を目的として Kocher 授動術を施行 していない910).

十二指腸授動を行わずに膡頭部操作を加えることは 若千手術手技に習熟を要する，しかし，脺頭部に支持 系をおき患者の右側に率引することおよび膵後面剩離 操作の際の術者の左示指の使い方を工夫することて， 安全に行うことが可能である.すすかち，左示指を十 二指腸前壁と膵頭部の境界にあて，左母指て膵頭部を めくるように操作し，操作がある程度進んだ状態で中 指と示指て脺頭部をはさみ，示指で後上十二指腸動脈 の拍動を感じながら丁寕に操作を進めることがコッと 言えよう（図 2B）。しかし，高度な慢性炎症をともな う場合には，剶離操作に困難を生じ，ついつい時間を 
表 1 諸家の DpPHR の比較

\begin{tabular}{|c|c|c|c|c|c|c|c|c|c|c|c|}
\hline \multirow{2}{*}{ 報告 者 } & \multirow{2}{*}{$\begin{array}{c}\text { 脺頭部の } \\
\text { 哭筫 }\end{array}$} & \multirow{2}{*}{ 脺尾部 } & \multirow{2}{*}{$\begin{array}{l}\text { Kocher } \\
\text { 授動術 }\end{array}$} & \multicolumn{4}{|c|}{ 血管処理 } & \multirow{2}{*}{ 胆道処理 } & \multirow{2}{*}{ 再 建 } & \multirow{2}{*}{ その他 } & \multirow{2}{*}{ 発表年 } \\
\hline & & & & GD & ASPD & PSPD & IPD & & & & \\
\hline Beger et al' & 残 存 & 授動せず & $(+)$ & 残存 & 残存 & 残存 & $\begin{array}{l}\text { 残存 } \\
(?)\end{array}$ & 温 存 & Roux-en-Y & $\begin{array}{l}\text { 再建は Puestow 法 } \\
\text { に準し側々吻合 }\end{array}$ & 1980年 \\
\hline Warren et al ${ }^{113}$ & 残 存 & 授 動 & $(+)$ & 残存 & 牫存 & 残存 & $\begin{array}{l}\text { 残存 } \\
\text { (?) }\end{array}$ & 温 存 & Roux-en-Y & & 1984年 \\
\hline 加藤 $5^{n, 8)}$ & 残 存 & $\begin{array}{l}\text { 完全遊離 } \\
+ \text { 脾摘 }\end{array}$ & $(+)$ & 残存 & 残存 & 残存 & $\begin{array}{l}\text { 残存 } \\
(?)\end{array}$ & 温 存 & Roux-en-Y & $\begin{array}{l}\text { Beger 変法 } \\
\text { 脺体尾部を遊離 }\end{array}$ & 1985年 \\
\hline 安田ら” & 残 存 & 授動せず & $(-)$ & 残存 & 切除 & 残存 & $\begin{array}{l}\text { 切除 } \\
\text { (?) }\end{array}$ & 温 存 & $\begin{array}{l}\text { 䇏は土二指 } \\
\text { 晹第二部に } \\
\text { 端㑡吻合 }\end{array}$ & $\begin{array}{l}\text { 盟道·消化管温 } \\
\text { 存式 }\end{array}$ & 1990年 \\
\hline 今泉 ${ }^{10}$ & 完全切除 & 授動せず & $(-)$ & 切除 & 切除 & 七刀除 & $\stackrel{\text { 切除 }}{(?)}$ & $\begin{array}{l}\text { 切離(十二指 } \\
\text { 腸第一部人 } \\
\text { 吻合) }\end{array}$ & $\begin{array}{l}\text { 脺は土二指 } \\
\text { 算第二部に } \\
\text { 端側吻合 }\end{array}$ & $\begin{array}{l}\text { 膵頭全切除術 } \\
\text { 消化管温存 }\end{array}$ & 1990年 \\
\hline $\begin{array}{l}\text { 著者ら } \\
\text { (症例 } 2 \text { ) }\end{array}$ & 完全切除 & 授動せず & $(-)$ & 残存 & 切除 & 残存 & 残存 & 温 存 & Roux-en-Y & $\begin{array}{l}\text { 脺頍全切除術 } \\
\text { 胆道温存 }\end{array}$ & 1995年 \\
\hline
\end{tabular}

要し策膜内の微少血管を損偒していることは否めな い.すなわち，術直後のドレナージ路としては，あま り期待しえないのではないだろうか.また十二指腸壁 内の静脈路の確保については, 上十二指腸静脈と十二 指腸第山部の腸間膜を確実に温存しうるならば充分で あると考えており，現在では，このような範囲での切 開，授動は許容範囲として手術を行っており，問題が ないと考えている.

再建法に関しては, Beger らの報告では Roux-en-Y 型の再建を行っているのに対し, 安田, 今泉らは十二 指腸第II部へ脺を端側吻合することで，より生理的な 消化機能を得られる方法をとっている(9)10). 著者らは, 十二指腸の血流が膵との吻合には不十分と判断し Roux-en-Y 型を採用した.十二指腸血流に問題のない 症例に対しては，今後積極的に膵十二指腸端側吻合を 施行し，両再建法を比較検討すべきと考えている.

また胆道に関しては生理的機能を重視し胆管を温存

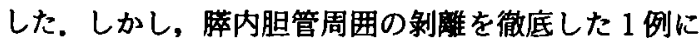
胆管壁の血流低下が原因と思われる胆道狭窄を経験し た。この点に関しては, 膵内胆管の剥離に際して, 胆 管周囲の膵組織，特に十二指腸側の膵組織を多少は残 すことで防止可能と考えている。

膵体尾部後方の神経叢郭清は, 術後長期の疼痛の再 発予防に有用であるという報告がある"．今回の 2 症 例では施行していないが，主膵管の非拡張症例では特 に重要とも考えられ，今後の検討課題として取り上げ て行きたい．報告では，10\%程度の症例で除痛が不十 分であったとされているが(表 2)，教室例では現在も 疼痛の再燃をみていない.
表 2 手術成績の比較

\begin{tabular}{c|lr|lr}
\hline 報 告 者 & \multicolumn{2}{|c|}{ 疼痛の状況 } & \multicolumn{2}{c}{ 社会復㷌の状況 } \\
\hline \multirow{3}{*}{ Beger et al } & 完全消失 & $77 \%$ & 完全復愲 & $67 \%$ \\
& まれに自覚 & $12 \%$ & 無職のまま & $13 \%$ \\
& しばしば自覚 & $11 \%$ & 不完全/不完全退職 & $20 \%$ \\
\hline 加藤ら & 充分な除痛 & $91 \%$ & 社会復㷌 & $92 \%$ \\
\hline 今泉ら & \multicolumn{2}{|c|}{ 良 好 } & 社会復愲 & $100 \%$ \\
\hline
\end{tabular}

本術式は消化管の持つ本来の機能を温存し得る手術 として有用であり，膵内・外分泌機能の低下が予想さ れる慢性勝炎症例に対しては適応があると考える。

\section{結 語}

1）膵頭部限局慢性膵炎症例に対して, DpPHR を施 行した.

2）合併症として，1 例に胆道狭窄を経験したが，拡 張術にて軽快した。

3）DpPHR は手術手技に習熟を要するものの, 消化 管の持つ本来の機能を温存し得る術式として有用であ ると考える。

$$
\text { 文献 }
$$

1) Beger HG, Krautzberger W, Bitter R, et al: Duodenum-preserving resection of the head of the pancreas in patients with severe chronic pancreatitis. Surgery $97: 467-473,1985$

2）諸星利男, 吉田悦子, 神田実喜男：アルコール性膵 炎の線維化の機序. 病理と臨 $10: 511-515,1992$

3）水本龍二，川原田嘉文：慢性膆㷋に対する手術術 式の選択と治療成績. 外科治療 47：501-509， 
1982

4）佐藤寿雄，宮下英士，松野正紀他：慢性脺炎に対す る手術適応と術式の選択およびその治療成績，外 科診療 $28: 19-25,1986$

5）今泉俊秀, 鈴木 衛, 羽生富士夫：慢性膀炎の手術 術式とその遠隔成續. 臨床内科 4:81-91, 1994

6）具 英成，斉藤洋一：慢性膵炎. 外科治療 68 ： 931-934, 1993

7）加藤紘之，奥芝俊一，池永治親他：十二指腸温存膆 頭切除術－Berger 変法. 胆と膵 $12: 1331-1337$ ， 1991

8）加藤紘之，下澤英二，奥芝俊一他：慢性膡炎に対す
る十二指腸温存膆頭切除術。手術 46：14131421,1992

9）安田秀喜, 高田忠敬 : 十二指腸温存脺頭切除一胆 道消化管温存術式一。胆と膵 $12 ： 1345-1352$, 1991

10）今泉俊秀, 羽生富士夫, 鈴木 衛他：十二指腸温存 膵頭全切除術. 消外 $14: 475-488,1991$

11) Warren WD, Millikan WJ Jr, Henderson JM, et al: A denervated pancreatic flap for control of chronic pain in pancreatitis. Surg Gynecol Obstet $159: 581-583,1984$

\title{
DUODENUM-PRESERVING PANCREAS HEAD RESECTION FOR CHRONIC PANCREATITIS -REPORT OF TWO CASES-
}

\author{
Masami KIMURA, Koichi HIRATA, Toshihiko MIKAMI, Ikuo OIKAWA, \\ Mitsuhiro MUKAIYA and Ryuichi DENNO \\ First Department of Surgery, Sapporo Medical University
}

Severe pain deriving chronic pancreatitis is often unable to be contrtolled by non-surgical treatments, therefore surgical treatment is required for such patients. We had been performed pancreaticoduodenectomy for those patients whose main lesion was located in the head of the pancreas and the main pancreatic duct did not dilate in the body or tail of the pancreas until 1990 . Since Beger reported duodenum-preserving pancreas head resection (DpPHR) in 1980, various modified DpPHRs have been attempted in several ways that are in discuss about their procedures and the principles. We also performed DpPHR in a different way on two cases of chronic pancreatitis with a lesion localized in the head. On endoscopic retrograde cholangio-pancreatogram (ERCP), each case revealed dilatation of the main pancreatic duct in the head and complained of severe abdominal pain. Preoperative diagnosis of one case was chronic pancreatitis localized in the head of the pancreas, and the other was suspected that the tumor was localized in the main pancreatic duct. Kocher's maneuver was not employed in both cases, and the all extrahepatic biliary tract was preserved. Reconstruction was made by an end to side anastomosis between the Roux-en-Y jejunal limb and the body of the divided pancreas. The two patients have been well up to now. Although it is still controversial in the maneuver, DpPHR for preserving the natural gastrointestinal function greatly contributes to the patient's quality of life. 